\title{
A Comparative Analysis of Physical Education Learning Motivation Based on the Provided Feedback Through Technical Approaches in a Middle School
}

\author{
Lutfi Nur*, Adang Suherman, Herman Subarjah, Dian \\ Budiana \\ Department of Sport Education, Postgraduate School \\ Universitas Pendidikan Indonesia \\ Bandung, Indonesia \\ *lutfinur@upi.edu
}

\author{
Arief Abdul Malik \\ Department of Physical Education \\ Universitas Siliwangi \\ Tasikmalaya, Indonesia
}

\begin{abstract}
Learning motivation is an important element in the learning process, so that it can run optimally. In this study, researchers analyzed the student motivation when attending physical education learning by providing positive feedback and neutral feedback through a technical approach. This research was a quasi-experimental research with counterbalanced design. Sixty students were involved as participants from the Laboratorium Percontohan UPI Junior High School, Indonesia. The instrument used to measure motivation was a physical education motivation instrument for junior high school children with 29 questions, including 5 aspects of indicators, namely 1) Perseverance in learning, 2) Resilient in facing difficulties, 3) Interest and sharpness of attention in learning, 4) Achievement in learning, and 5) Independence in learning. The instruments were tested for their validity and reliability with the results of the scores were 0.518 and 0.906 . The results of this study show that giving positive feedbacks contributes to a greater motivation score than providing neutral feedbacks in physical learning by using a technical approach. The findings indicate that the effective application of feedback can be used as a way to increase the student motivation.
\end{abstract}

Keywords: learning motivation, physical education, approaches

\section{INTRODUCTION}

Motivation is one of the psychic aspects that drives a person to express the ability of an action to achieve the desired goal $[1,2]$. In a learning process, motivation is one of the keys in an effort to achieve a learning goal. Students with good learning motivation tend to follow the teaching and learning process in class well. On the other hand, students who are less motivated will also tend to have less the learning process so that the learning outcomes tend to be less optimal. This is in accordance with previous research studies by Richards and Levesque-Bristol which revealed that students who are intrinsically motivated consider physical education important learning because it is more fun than doing an assignment in the classroom. Physical education motivation has essential role in enhancing students' perceived physical competence therefore it can be analyzed in order to run the physical education learning well [3]. For example, the results of other studies state that the sport education learning model can increase motivation and intensity of motion learning in adolescent students and early adult students at the age of 16 years $[4,5]$. In line with this, Gao revealed that the types or models of physical activity games in Physical Education learning have a great influence on learning motivation, physical activity participation rates or Physical Education learning activities and perseverance in learning [6]. Learning models of engineering models improve the perfection of technique or skill. However, this learning model is criticized because it tends to be too monotonous and makes students less enthusiastic when following the learning process. Therefore, giving feedback on this learning model is thought to increase student arousal when participating in learning.

Feedback is the provision of information in a programmed, interactive manner and uses certain techniques in responding to student performance results [7]. In learning, students often need help finding answers, why their work is wrong [8,9]. Therefore, by providing feedback on ongoing evaluation is expected to stimulate students to be more active in learning, trying to correct deficiencies and then build understanding in the right direction. In addition, with feedback the teacher realizes his shortcomings.

Furthermore, the aim of this study is to analyze student learning motivation by applying a technical learning model accompanied by providing positive and neutral feedback.

\section{MethoD}

The research method used in this study is counterbalanced design. Participants in this study were 60 students of Laboratorium Percontohan UPI Junior High School which were divided into 2 groups. Each group gets the same treatment that is getting technical learning model learning with positive feedback and technical learning models with neutral feedback. The instrument used in this study was a physical education motivation instrument for junior high school children with 29 questions including 5 aspects of indicators, namely 1) Perseverance in learning, 2) Resilient in facing difficulties, 3) Interest and sharpness of attention in learning, 4) Achievers in learning, and 5) Independent in learning. The results of the study were analyzed descriptively to determine the differences 
in the feedback given. Motivational instruments using the Guttman Scale are used for answers that are clear (firm) and consistent $[4,10]$. Then the data were analyzed using statistical descriptive analysis techniques with the help of SPSS version 23.

\section{RESULTS AND DISCUSSION}

The research data illustrates the motivation of students in participating in Physical Education learning in junior high schools. The descriptive summary of the overall research data is as follows (see table 1).

Results the maximum score that can be obtained for the aspect 1 st category is 420 , the aspect 2 nd category is 360 , the 3 rd aspect category is 240 , the 4 th aspect category is 300 , and the 5 th aspect category is 420 . In Table 1 shows the results of measuring the learning motivation of Physical Education learning in junior high schools. The total motivation score obtained by 60 students as a whole on giving positive feedback was 1163, while on giving neutral feedback was 1042 with the percentage of achievement on positive feedback of $66.84 \%$ and the percentage of achievement of neutral feedback was $59.89 \%$. The highest student learning achievement motivation overall is in the aspect 1st category with $70.00 \%$ achievement, while the lowest student learning achievement in the 3rd aspect category with $60.42 \%$ achievement on giving positive feedback. On the other hand, physical education learning achievement in providing neutral feedback obtained the highest achievement in the 1st aspect with an achievement of $66.19 \%$ and the lowest in 3rd aspect with $55.00 \%$ achievement.

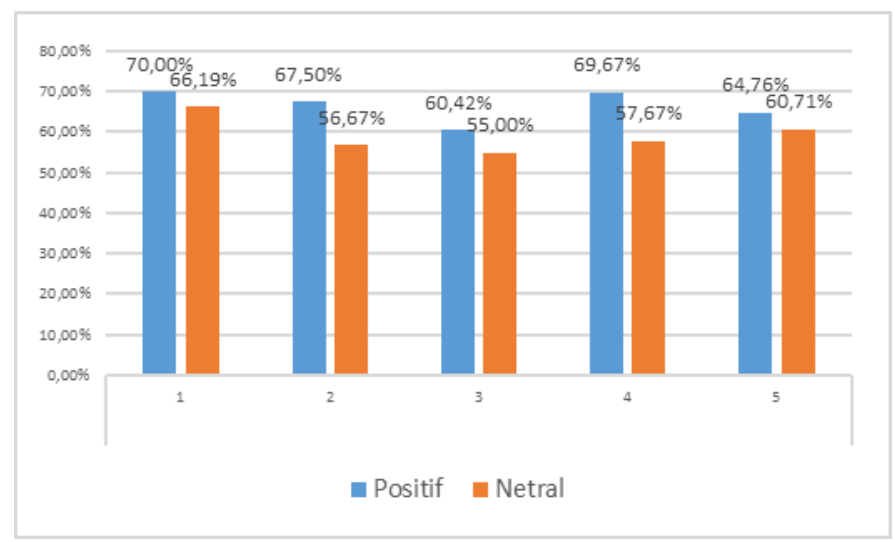

Fig. 1. Percentage Graph of physical education student learning motivation.

In addition, in detail the results of student physical education learning achievement achievements based on each sub-category category are shown in Figure 1. Giving positive feedback gets the highest average results from all aspects of the category compared to neutral feedback. Sequentially, the highest percentage of positive feedback is aspect 1 with $70.00 \%$, aspect 4 with $69.67 \%$, aspect 2 with $67.50 \%$, aspect 5 with $64.76 \%$ and finally aspect 3 with $60.42 \%$. In giving neutral feedback, sequentially namely aspect 1 , aspect 5 , aspect 4 , aspect 2 , and aspect 3 with percentage scores for each aspect are $66.19 \%, 60.71 \%, 57.67 \%, 56.67 \%$, and $55.00 \%$.

In Figure 2, we can see the difference in cycle 1 and cycle 2 giving feedback. In cycle 1 , giving positive feedback received an average score of 18.94 , while giving neutral feedback got a score of 16.96 with a difference of 1.98 . In cycle 2 , the acquisition position is still relatively the same, namely giving positive feedback a score of 19.86 higher compared to giving neutral feedback which scores 17.74. The difference between the two feedbacks is 2.12 . The average acquisition of positive feedback and overall neutral feedback as shown in Figure 3. The application of technical learning models accompanied by positive feedback gives an average score of 19.40, while the application of technical learning models with neutral feedback is only obtained an average of 17.35 , with the difference between the two of 2.05 .

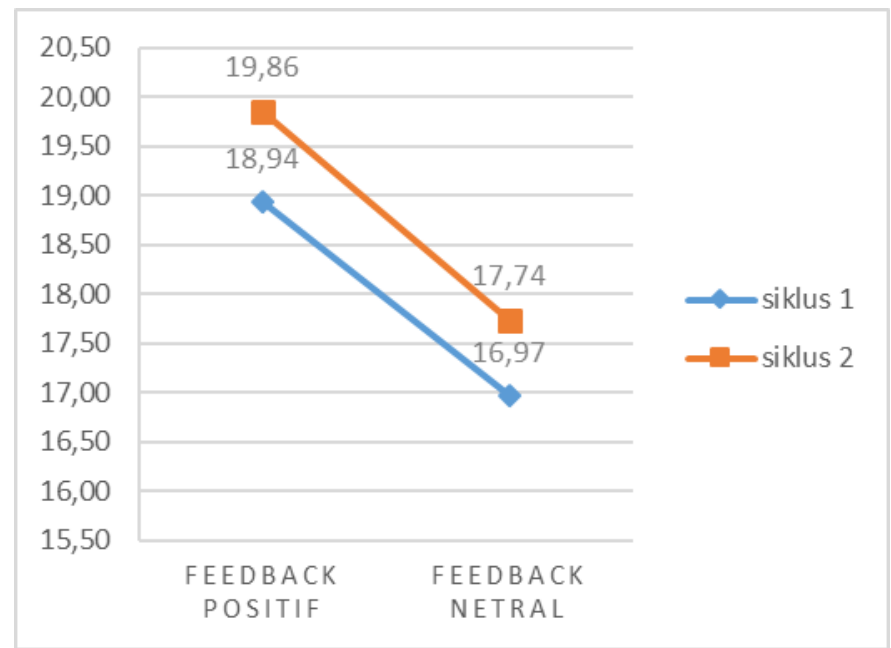

Fig. 2. Percentage graph of physical learning motivation for physical education students in the cycle 1 and cycle 2 .

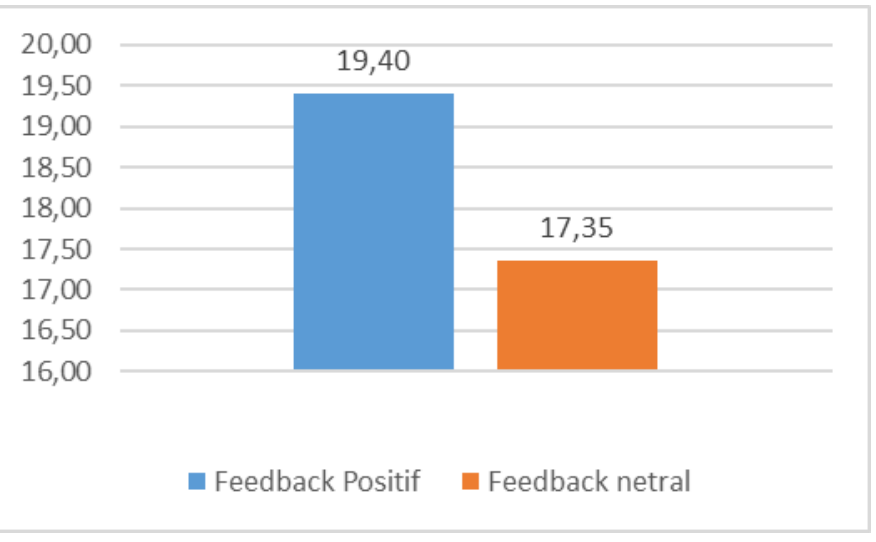

Fig. 3. Overall graphic percentage of student physical education learning motivation.

Based on the research findings, it appears that providing feedback can provide a significant difference in effect when applied to technical learning models. This is in accordance with what Suherman said that the benefits of using feedback include encouraging students to practice, reflect effective teacher behaviour, help students to assess performances that cannot be seen and felt by themselves, and encourage teachers to assess how relevant and how quickly each child has learned the skills his teacher wants [11]. In line with previous studies, that providing motivation can improve students' playing skills [12]. 


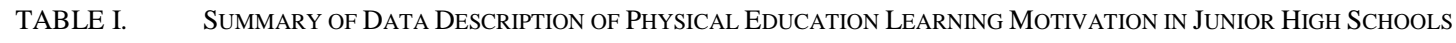

\begin{tabular}{|c|c|c|c|c|c|c|c|c|}
\hline \multirow{2}{*}{$\begin{array}{c}\text { Aspect } \\
\text { Category }\end{array}$} & \multicolumn{2}{|c|}{ Study 1} & \multicolumn{2}{|c|}{ Study 2} & \multicolumn{2}{|c|}{ Overall } & \multicolumn{2}{|c|}{ Percentage of Overall Achievement } \\
\hline & Positive & Neutral & Positive & Neutral & Positive & Neutral & Positive & Neutral \\
\hline 1 & 154 & 128 & 140 & 150 & 294 & 278 & $70.00 \%$ & $66.19 \%$ \\
\hline 2 & 116 & 108 & 127 & 96 & 243 & 204 & $67.50 \%$ & $56.67 \%$ \\
\hline 3 & 74 & 65 & 71 & 67 & 145 & 132 & $60.42 \%$ & $55.00 \%$ \\
\hline 4 & 102 & 83 & 107 & 90 & 209 & 173 & $69.67 \%$ & $57.67 \%$ \\
\hline 5 & 141 & 108 & 131 & 147 & 272 & 255 & $64.76 \%$ & $60.71 \%$ \\
\hline Total & 587 & 492 & 576 & 550 & 1163 & 1042 & $66.84 \%$ & $59.89 \%$ \\
\hline
\end{tabular}

Based on the results of research, theories, and previous research findings show that the achievement of Physical Education learning motivation in elementary schools must be developed and improved so that Physical Education learning can run optimally.

\section{CONCLUSIONS}

Providing feedback in physical education learning has a very important role in improving the quality of teaching and learning. The results of this study indicate that the provision of positive feedback has a better contribution compared to the giving of neutral feedback. Through the findings of this study, in addition to providing reinforcement of the importance of feedback interventions, physical education teachers can implement the provision of feedback in the teaching and learning process of physical education in schools.

\section{REFERENCES}

[1] V. Gopalan, J. A. A. Bakar, A. N. Zulkifli, A. Alwi, and R. C. Mat, "A review of the motivation theories in learning," in AIP Conference Proceedings, 2017, vol. 1891, no. 2017.

[2] E.L. Deci and R. M. Ryan, "The 'what' and 'why' of goal pursuits: Human needs and the self-determination of behavior," Psychol. Inq., vol. 11 , no. 4 , pp. 227-268, 2000.
[3] K.A.R. Richards and C. Levesque-bristol, "Student Learning and Motivation in Physical Education," Strateg. A J. Phys. Sport Educ., vol. 27, no. 2, pp. 43-46, 2015.

[4] R. Hartono, A. Suherman, and A. Rusdiana, "Pengaruh Model Sport Education Terhadap Motivasi dan Intensitas Gerak," Edusentris, Ilmu Pendidik. dan Pengajaran, vol. 1, no. 3, pp. 213-226, 2014.

[5] T.L. Wallhead and N. Ntoumanis, "Effects of a Sport Education Intervention on Students ' Motivational Responses in Physical Education," J. Teach. Phys. Educ., vol. 23, pp. 4-18, 2004.

[6] Z. Gao, A. M. Lee, P. Xiang, and M. Kosma, "Effect of Learning Activity on Students ' Motivation , Physical Activity Levels and Effort / Persistence," J. Rsearch, vol. 6, no. 1, pp. 27-33, 1997.

[7] J. Hattie and H. Timperley, "The Power of Feedback," Rev. Educ. Res., vol. 77, no. 1, pp. 81-112, 2007.

[8] G. E. İLKER and H. AŞÇI, "The Role of Teacher s Feedback in Physical Education: Motivational Climate as Mediator," Hacettepe Üniversitesi Eğitim Fakültesi Derg., vol. 34, no. 2, pp. 372-386, 2019.

[9] A. Koka and V. Hein, "The Effect of Perceived Teacher Feedback on Intrinsic Motivation in Physical Education," Int. J. Sport Psychol., vol. 36, no. 2, pp. 91-106, 2005.

[10] R. E. Tractenberg, F. Yumoto, P. S. Aisen, J. A. Kaye, and R. J. Mislevy, "Using the Guttman Scale to Define and Estimate Measurement Error in Items over Time: The Case of Cognitive Decline and the Meaning of "“ Points Lost,"” PLoS One, vol. 7, no. 2, 2012.

[11] A. Suherman, Revitalisasi Pengajaran dalam Pendidikan Jasmani. Bandung: CV. Bintang Warli Artika, 2009.

[12] I. Nur, A. Hafina, N. Rusmana, and A.A. Malik, "Can Teaching by Invitation Technique Improve the Students' Basic Motion Ability? BT 1 st International Conference on Education Social Sciences and Humanities (ICESSHum 2019),” 2019. 